\title{
COMPETITIVENESS ANALYSIS OF KAZAKHSTAN CONFECTIONARY SECTOR USING FINANCIAL DISCRIMINANT MODELS
}

\author{
Petr Hájek, ${ }^{1}$ Gulnar Zhunissova, ${ }^{2}$ Tat’jana Čábelová, ${ }^{3}$ Adilya Baidildina ${ }^{4}$
}

\begin{abstract}
Measuring competitiveness offers hundreds of analytical options. We have chosen to analyze and compare companies of confectionery sector in Kazakhstan. We opted to use bankruptcy and creditworthiness models and compare competitiveness through the financial situation of main competitors on that market. Companies analyzed comprise of two Ukrainian companies (Konti and Roshen), Russian companies (Nestlé Russian branch serving also Central Asian markets and KDV - Yaskino) and three local corporations Rakhat, Bayan Sulu and Konfety Karagandy. Models used for analysis are Altman z-score model, Taffler z-score model, IN99, IN01, IN05, and creditworthiness model. The IN models were created in the Czech Republic based on companies' data from the 1990s which was the period of higher inflation, small currency an big banking crisis, massive imports, developing competition and infrequent political turmoil. These models have comparably much greater benefits for analyzing companies in Kazakhstan because they are based on hundreds of companies in contrast to tens of companies on which Altman or Taffler based their famous and highly predictive models. We present an analysis of models in $2007-2016$ period based on publicly accessible data. We show the IN models have valuable benefits for comparison compared with other older models and that they can disclose certain events or corporate situations in a clearer way than other Altman or Taffler z-score models and should be used in Kazakhstan and improved to suit better the local market environment.
\end{abstract}

JEL Classification Numbers: G32, G33; DOI: http://dx.doi.org/10.12955/cbup.v5.916

Keywords: bankruptcy, valuation, sweets, creditworthiness, IN models, Altman, competitiveness, Taffler, z-score model.

\section{Introduction}

Kazakhstan is a large country, very rich in many resources and home to 138 nationalities. What all these nationalities love are sweets. Confectionery business in Kazakhstan is famous and produces great quality products. Unfortunately, in last ten years had to adapt to many changes, including cocoa prices significant changes multiplied by the depreciation of tenge, and growth and recession periods of the Kazakhstan's economy. Regardless, citizens never stopped buying the sweets.

The financial analysis offers many models to analyze the likelihood of bankruptcy or solvency conditions that usually serve only to company financial director or investment companies for their decision-making about buying or selling shares. Analyses comparing companies from almost any whole sector in Kazakhstan are nonexistent.

We have decided to change this situation and analyze companies that cover a significant portion of confectionery business in Kazakhstan altogether (see data chapter for individual companies analyzed). That includes companies from Kazakhstan, Russian Federation, and Ukraine.

To proceed with such an analysis, we have selected models used in the EU and USA, but also frequently used models in the Czech Republic, which were developed using data from thousands of companies compared to tens of the Altman or Taffler models.

The objective of this research paper is to compare and comment results of various financial analysis models using publicly accessible accounting data since 2007 , recommend changes to some models while analyzing usefulness (positives and negatives) of such models under Kazakhstan economy conditions.

\section{Economic environment}

Ten years ago, in 2007, started a subprime banking crisis in the USA. It sparked global recession and crises on various asset markets around the world during next 2-3 years including Kazakhstan. The banking sector in Kazakhstan was hit and credit market froze. That resulted in a Government intervention. During the great recession the price of the main export product of Kazakhstan, the oil, plummeted. Its price has a significant influence on the exchange rate of tenge to USD.

Since then it is hard and expensive to get any credit. Banks are very risk-averse, and interest expenses of companies are high when compared to the EU countries, or countries in the Eastern Europe. Table 1 shows the situation: inflation is increasing with the depreciation of tenge. To limit the inflation, the

\footnotetext{
${ }^{1}$ Unicorn College, and Central Bohemia University, Prague, Czech Republic, hajekp@ gmail.com

${ }^{2}$ Higher school of economics, Al Farabi National University, Almaty, Kazakhstan, nietbaeva_gulnar@mail.ru

${ }^{3}$ Central Bohemia University, Prague, Czech Republic, tana.Cabelova@ seznam.cz

${ }^{4}$ Higher school of economics, Al Farabi National University, Almaty, Kazakhstan, Adilya.Baydildina@kaznu.kz
} 
central bank decided to increase target interest rate, which led to skyrocketing interest expenses of all indebted companies. Consumer expenditures (where spending on sweets belongs) show slow growth in last two years as GDP growth does. Therefore, we can expect citizens to be buying relatively smaller amounts of sweets and thus production and sales of the confectionery industry cannot be expected to rise significantly.

Main import commodity and unreplaceable production input for confectionery industry is cocoa. See Figure 1 for price fluctuations in KZT and USD on world markets. We can see that cocoa prices started to significantly increase during fall of 2014 to reach multiples of prices that were common between 2007 and 2013. The same chart also shows a significant increase of USDKZT exchange rate affecting negatively (concerning costs) other imported commodities for whole industry as well. Besides mentioned expenses on cocoa, the sector also faces other import tariffs and price fluctuations for sugar, nuts and other ingredients not produced in Kazakhstan, or in the countries of the Customs Union.

\begin{tabular}{|l|c|c|c|c|c|c|c|c|c|c|c|c|}
\hline Table 1: Selected indicators of Kazakhstan economy \\
\hline Indicator & 2007 & 2008 & 2009 & 2010 & 2011 & 2012 & 2013 & 2014 & 2015 & 2016 & Source \\
\hline CPI [\% YoY change] & 10.8 & 17.2 & 7.3 & 7.1 & 8.3 & 5.1 & 5.8 & 6.7 & 6.6 & 14.5 & WB \\
\hline CPI [2010=100] & 74.3 & 87.0 & 93.4 & 100.0 & 108.3 & 113.9 & 120.5 & 128.6 & 133.2 & 157.1 & IFS \\
\hline $\begin{array}{l}\text { Central Bank Policy } \\
\text { Rate [\% p.a.] }\end{array}$ & 11.0 & 10.5 & 7.0 & 7.0 & 7.5 & 5.5 & 5.5 & 5.5 & 16.0 & 12.0 & IFS \\
\hline $\begin{array}{l}\text { USDKZT [Period } \\
\text { Average] }\end{array}$ & 122.6 & 120.3 & 147.5 & 147.4 & 146.6 & 149.1 & 152.1 & 179.2 & 221.7 & 342.2 & IFS \\
\hline GDP growth [\% p.a.] & 8.9 & 3.3 & 1.2 & 7.3 & 7.4 & 4.8 & 6.0 & 4.2 & 1.2 & 1.0 & WB \\
\hline $\begin{array}{l}\text { Household final } \\
\text { consumption, [\% YoY } \\
\text { change, constant KZT] }\end{array}$ & 10.8 & 6.9 & 0.7 & 11.2 & 11.9 & 10.3 & 10.4 & 1.5 & 1.8 & n/a & $\begin{array}{c}\text { WB, } \\
\text { Authors }\end{array}$ \\
\hline
\end{tabular}

Source: (IMF, 2017), (World Bank, 2017), own calculations based on WB Data.

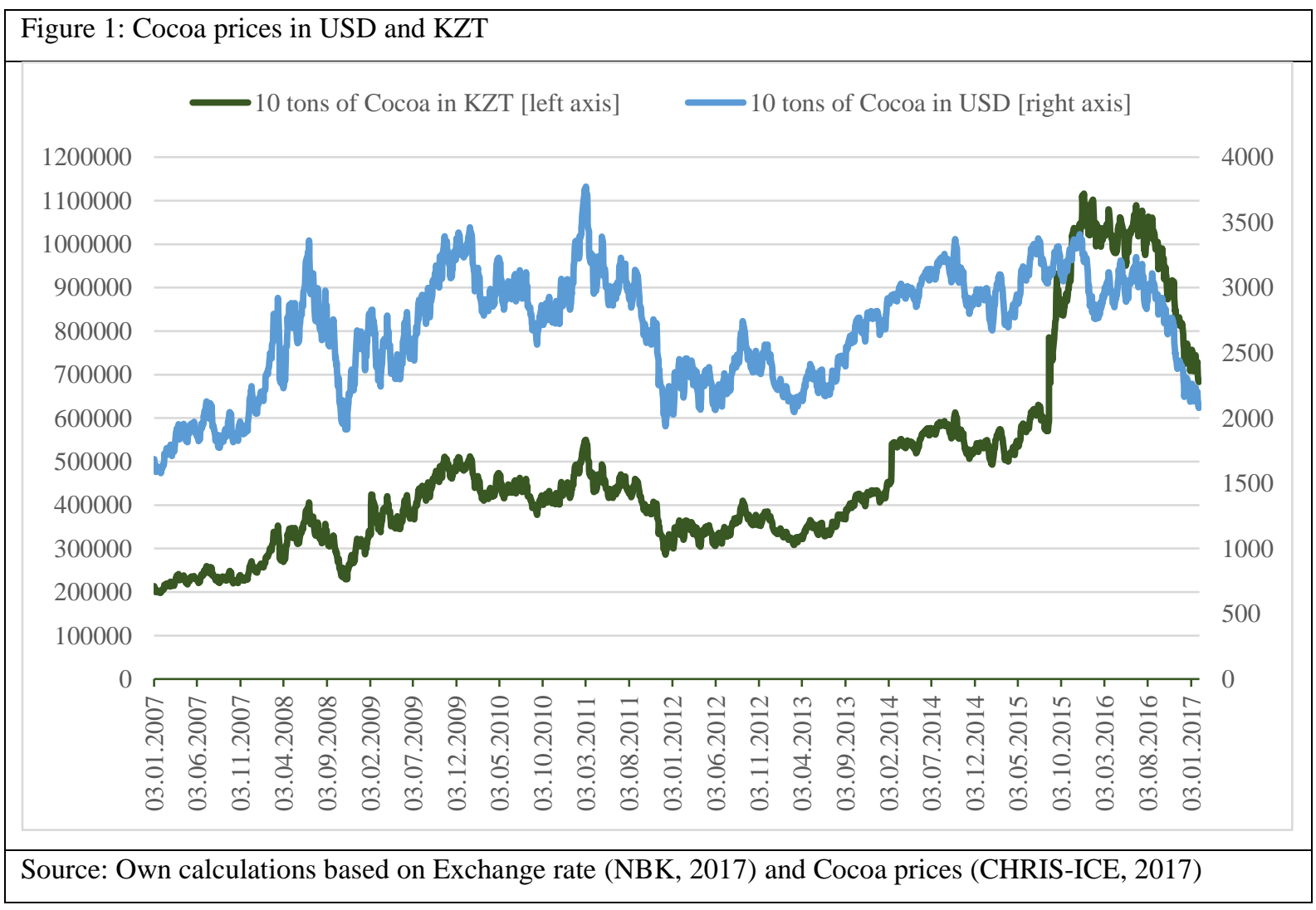

According to (Euromonitor, 2016) the import duty on the cocoa product has been reduced by Eurasian Economic Commission at the start of 2017 from 3-5\% to $0 \%$ of the customs value. The $0 \%$ will apply to non-defatted cocoa paste, cocoa butter, and cocoa fat. The new tariff will not affect Rakhat, Bayan Sulu and Konfety Karagandy (further referred as KK) because they have their own cocoa beans 
processing facilities. However, other local companies, such as Hamle (bought in 2017 by Ulker Biskuvi Sanayi for 3 mil. USD) and Almatinskiy Produkt (producing mostly Helva and other cheap products that are less popular), do not have the equipment for roasting and processing cocoa beans.

\section{Data and Market Description}

We have decided to analyze companies covering a significant portion of the market for confectionery products in Kazakhstan. Selected companies originate from three countries: Kazakhstan (Rakhat, Bayan Sulu, Konfety Karagandy), Russian Federation (Nestle Russia, KDV - Yaskino) and Ukraine (Roshen, Konti). Analysed data were downloaded from publicly available sites: for Rakhat from (Rakhat reporting, 2017), for Bayan Sulu from (Bayan Sulu reporting, 2017), for Konfety Karagandy from (Konfety Karagandy reporting, 2017), for KDV Yaskino from (KDV - Yaskino reporting, 2017), for Roshen from (Roshen reporting, 2017), for Konti from (Konti reporting, 2017), and for Nestle Russia from (Nestle reporting, 2017). Due to data availability and for easier comparison we have limited data used for ten years between years 2007 and 2016.

\begin{tabular}{|c|c|c|c|c|c|}
\hline Market share & 2012 & 2013 & 2014 & 2015 & 2016 \\
\hline Rakhat & 38.6 & 40.2 & 41.1 & 40.5 & 38.6 \\
\hline Bayan Sulu & 17.9 & 21.6 & 21.8 & 19.1 & 21.7 \\
\hline Konfety Karagandy & 4 & 3.1 & 3.4 & 4.3 & 2 \\
\hline Russian producers & 27.81 & 24.89 & 23.96 & 22.63 & 25.15 \\
\hline Ukrainian producers & 9.16 & 7.60 & 7.28 & 11.77 & 7.95 \\
\hline Other CIS producers & 0.32 & 0.28 & 0.20 & 0.22 & 0.75 \\
\hline Other foreign producers & 1.98 & 2.24 & 2.29 & 1.52 & 2.71 \\
\hline
\end{tabular}

According to (Rakhat, 2017) the market for sweets is close to saturation. The trend of sweets consumption growth rate is decreasing in last few years. Because of the significant weakening of the national currency, a reduction in income and a decrease in the purchasing power of the population led to the concentration of sales moving to a cheaper segment of the market: consumers turned from more expensive chocolate to cheaper confectionery products as cookies, waffles, and caramels. The market has the capacity of 227000 tons with domestic companies producing 183000 tons of which 68800 tons is exported, and another 112800 tons imported (mostly Russia and Ukraine as seen from Table 2).

\section{Results and Discussion}

To analyze financial trends of individual companies, we have selected (considering the availability of indicators) the following bankruptcy and creditworthiness models: Altman z-score model, Taffler zscore model, IN99, IN01, IN05, and Creditworthiness index.

Certain peculiarity making hard any such analysis in Kazakhstan is sometimes unclear accounting terminology resulting in problematic "translation" of certain indicators used in various models in other countries. It would be impossible to do such an analysis without consultations with local accounting experts knowing the specific terminology of indicators in each Czech, English and Kazakh environment. Our experience is that research based on a plain translation of indicators from local websites would be unusable. For the purpose to clear doubt for anybody, who would like to replicate our analysis, we present a three-language terminology table of indicators used (see Annex).

These models belong to the group of indicator systems, which are supposed to assess the financial situation of the company. Since the values of these indicators are very important for banking institutions, when deciding about granting or rejecting a credit. Their purpose is to eliminate limitations and potentially missing information discovered by the ratios. (Kislingerová, 2008)

Creditworthiness models examine the financial health of a company based on macroeconomic and microeconomic principles and also on an experience and knowledge of the financial analyst. Creditworthiness models assess the financial health of the company in comparison with other companies, or they use a point system, in which the companies are classified according to their financial situation. (Grünwald, 2007)

As (Kislingerová, 2008) points out: the purpose of the bankruptcy models is to predict a threat to the financial health of the analyzed company and the likelihood of bankruptcy. The term financial distress 
represents a state of the company in which it is not capable of settling its debts, or the value of its debts exceeds the value of its assets. In other words when a company becomes illiquid or insolvent.

Altman Z-score

According to (Vochozka, 2011) the Altman Z- score belongs to the group of bankruptcy models. This model is named after Prof. Edward Altman who on the grounds of several ratios and statistical analysis managed to evaluate the bankruptcy likelihood of the company or the probability of decline two years in advance and with up to $70 \%$ success rate five years in advance. According to (CRF, 2017), the zscore is known to be about $90 \%$ accurate in forecasting business failure one year into the future and about $80 \%$ accurate in forecasting it two years into the future.

Prof. Altman constructed it by using discriminant analysis with five ratios used in the equation, according to which is possible to identify a bankrupting company. (Vochozka, 2011)

$$
Z=1.2 * X(1)+1.4 * X(2)+3.3 * X(3)+0.6 * X(4)+1.0 * X(5)
$$

Where: $\quad X(1)=($ working capital [current assets - shortterm liabilities] / total assets

$X(2)=$ retained earnings $/$ total assets

$X(3)=$ EBIT $/$ total assets

$X(4)=$ market value of equity / book value of debt

$X(5)=$ sales $/$ total assets
Z> 2.99 the business is in a good position, financially healthy

$1.81<\mathrm{Z}<2.99$ gray zone of unmatched results

$\mathrm{Z}<1.81$ bankruptcy has significant probability

The higher values of the Z- score, the financially healthier the company is.

Table 3: Results of Altman z-score model

\begin{tabular}{|l|c|c|c|c|c|c|c|c|c|c|}
\hline & $\mathbf{2 0 0 7}$ & $\mathbf{2 0 0 8}$ & $\mathbf{2 0 0 9}$ & $\mathbf{2 0 1 0}$ & $\mathbf{2 0 1 1}$ & $\mathbf{2 0 1 2}$ & $\mathbf{2 0 1 3}$ & $\mathbf{2 0 1 4}$ & $\mathbf{2 0 1 5}$ & $\mathbf{2 0 1 6}$ \\
\hline Rakhat & 4.21 & 4.54 & 5.53 & 7.01 & 7.92 & 7.54 & 6.72 & 6.73 & 6.46 & 6.68 \\
\hline Bayan Sulu & 1.27 & 1.53 & 1.07 & 3.22 & 2.83 & 3.27 & 3.18 & 2.90 & 2.30 & 4.91 \\
\hline Konfety K. & 2.54 & 2.38 & 2.73 & 1.86 & 2.26 & 2.68 & 3.28 & -0.66 & $\mathbf{- 1 6 . 4 3}$ & $\mathbf{- 3 . 8 4}$ \\
\hline Nestle & 0.91 & 1.01 & 1.12 & 1.14 & 1.19 & 1.22 & 2.13 & 2.01 & 2.09 & 1.89 \\
\hline Roshen & 1.83 & 1.25 & 1.76 & 1.33 & 5.13 & 1.61 & 3.98 & 2.56 & 3.09 & 3.18 \\
\hline KDV-Yaskino & 2.92 & 2.71 & 3.87 & 4.26 & 2.79 & 2.20 & 1.83 & 1.44 & 1.71 & 2.04 \\
\hline Konti & 2.58 & 2.57 & 2.52 & 1.89 & 1.77 & 2.79 & 2.91 & 2.94 & 2.22 & 2.06 \\
\hline
\end{tabular}

We can see Konfety Karagandy faced several important events in 2014. First 24 Jan 2014 the main shareholder of the Apex's way (Kazakhstan) sold $90 \%$ of shares (all they owned) to Centis International Ltd. (British Virgin Islands). Apex way owned the shares only since December 2013 when they bought them from British UIG Ltd. According to the decision of the Novosibirsk region, Arbitration court the KK owed 221,045,487 RUB past due to trading company Armatele LLC. The debt has to be paid by the end of the year 2017 (Konfety Karagandy, 2015). Then on February 11, tenge devalued by $20 \%$ against US dollar, which significantly increased the dollar value of KK foreign debt. After the change of ownership, the KK went through a restructuring in 2014, changed management, and with decreasing sales since then through early summer of 2016 they decided to shut the production completely down to buy new equipment. (NovoeTV, 2016). Date of production reopening is unknown.

We can see several companies struggled to survive during the Great Recession and frozen credit market. Nestle managed to survive with support from the holding company in Switzerland. Bayan Sulu struggled through the whole recession because of a significant increase in the volume of receivables. Also, the company received new credit and sold owned shares to increase its financial situation. Roshen faced a similar environment in Ukraine and got out from it with a significant increase in liabilities and bank credit in 2008, and 2009 respectively. Bank credits increased until 2011 and in 2012 started to decrease. In 2007 Nestlé had almost ten-fold volume of Short-term financial investments (probably shares to improve financial stability) compared to other years. KDV-Yaskino took in 2015 lots of bank credit to survive the long-term liabilities that skyrocketed in 2014.

In 2010 Roshen started to invest into the construction of a new factory in Lipetsk region of Central Russia which finished in 2013 and cost 250 mil. USD. (Focus, 2010). In 2013 Roshen after the approval of the annual accounts for the 2011-2012 revealed the fact of overstating net costs and understating the profit for 2011 and 2012. The identified error led to the increase in taxable profits in 2011 and 2012, and the additional payment of 1,307,789.79 RUB profit tax. (Roshen, 2014). The factory in Lipetsk was 
closed in March 2014 due to problems that emerged during the Russian annexation of Crimea which happened 20 Feb 2014 - 19 Mar 2014. (BBC, 2014)

Taffler's model (Růčková modification)

It is a bankruptcy model that indicates the probability of bankruptcy of the company. The model was published in 1977. (Atlantis, 2017) Taffler's z-score model discrimination function has the form of modification of (Rủčková, 2011) with four ratios.

$$
T Z=0.53 * R 1+0.13 * R 2+0.18 * R 3+0.16 * R 4
$$

Where: $R 1=$ Earnings before taxes / short-term liabilities $R 2=$ current assets $/$ liabilities

$R 3=$ short-term liabilities $/$ total assets $R 4=$ sales $/$ total assets
$\mathrm{TZ}>0.3$ low probability of bankruptcy of the company $0.2<\mathrm{TZ}<0.3$ gray zone of unmatched results

$\mathrm{TZ}<0.2$ increased probability of bankruptcy of the company

The original version of Taffler's model uses the share of financial assets net of current liabilities to operating costs instead of sales to total assets and does not use gray zone. When evaluating the original Taffler's Model, the gray zone is not used. Enterprises are classified according to the index outcome only on bankruptcy and credibility; zero is the critical value for the determining the category. A positive index corresponds with credit business and vice versa. (Vochozka, 2011)

Růčková (2011) used the same breakdown of enterprises according to the established value of the Taffler's Model. Rather than evaluating enterprises as creditworthy, she states that the company has a small probability of bankruptcy and instead of bankruptcy enterprises says that the company has a high probability of bankruptcy.

The [Taffler] model is shown to have the clear predictive ability over time period [of 25 years] and dominates more naïve prediction approaches. [This] study also illustrates the economic value to a bank of using such methodologies for default risk assessment purposes. (Agarwal \& Taffler, 2007)

\begin{tabular}{|c|c|c|c|c|c|c|c|c|c|c|}
\hline & 2007 & 2008 & 2009 & 2010 & 2011 & 2012 & 2013 & 2014 & 2015 & 2016 \\
\hline Rakhat & 0.91 & 0.71 & 1.32 & 1.98 & 3.06 & 3.05 & 2.92 & 3.26 & 2.21 & 2.47 \\
\hline Bayan Sulu & 0.38 & 0.39 & 0.35 & 0.66 & 0.75 & 0.70 & 0.63 & 0.59 & 0.59 & 0.53 \\
\hline Konfety K. & 0.43 & 0.51 & 1.98 & 1.43 & 2.06 & 1.68 & 0.73 & -0.60 & -0.66 & -2.68 \\
\hline Nestle & 0.46 & 0.52 & 0.53 & 0.55 & 0.50 & 0.54 & 0.55 & 0.53 & 0.53 & 0.52 \\
\hline Roshen & 0.68 & 0.84 & 0.55 & 0.46 & 1.51 & 0.38 & 0.51 & 1.13 & -0.24 & 0.16 \\
\hline KDV-Yaskino & 0.79 & 0.81 & 1.27 & 1.25 & 0.56 & 0.46 & 0.35 & 0.40 & 0.33 & 0.47 \\
\hline Konti & 0.62 & 0.60 & 0.60 & 0.47 & 0.47 & 0.67 & 0.70 & 0.70 & 0.58 & 0.59 \\
\hline
\end{tabular}

We have already described the KK situation. The Roshen company became a victim of war in Ukraine and shut down newly built Russian factory. The loss of rich Donbas to pro-Russian separatists caused a significant loss in 2015 for many Ukrainian firms, causing an increase in debt and interest expenses.

\section{IN Models - Credibility indexes}

According to (Neumaier \& Neumaierová, 2002) the IN models belong to the group of bankruptcy models and were created for the conditions of the restructuring Czech market during the 1990s. The authors using discriminant analysis, ratios and weighted mean values created a function for identification of bankrupting companies. IN models has gone through several phases of evolution, the first being the IN95 index, which focused on the company from the creditor's point of view and included Past due liabilities, an indicator not being published by companies in Kazakhstan (so we cannot use it in our analysis). Then the IN99 index followed, which assessed the company from the perspective of the owner. These two resulted in bankruptcy index IN01, which connects both of the previous indexes and also includes the economic added value. The last version emerged in 2005 when IN01was updated into the bankruptcy index IN05 (Neumaierová \& Neumaier, 2005).

\section{IN99 Index}

$$
\text { IN99 }=-0.017 * A+4.573 * C+0.481 * D+0.015 * E
$$


Where:

$A=$ assets / liabilities

$C=$ EBIT $/$ total assets

$D=$ sales $/$ total assets

$E=$ current assets $/$ short-term

liabilities
IN99 $>2.07$ The company creates a new value for the owner (dark green)

$1.42<=$ IN99 $<2.07$ Rather it creates value for the owner

$1.089<=$ IN99 $<1.42$ It is not possible to determine whether or not company creates value for the owner

$0.684<=$ IN99 < 1.089 Rather does not create value for the owner

IN99 $<0.684$ Enterprise does not create value for the owner (dark red)

The IN index may be an appropriate indicator of value creation, especially if it is not possible to work with market prices for a company's shares due to their low ability to provide information or if no equity cost can be determined. With the success rate of $86.4 \%$, the index proves the value creation and with an even higher rate of success $98.9 \%$ has been able to identify that there is no value creation. (Atlantis, 2017)

According to (Atlantis, 2017) the construction was based on a discriminatory analysis and was based on the data of 1915 enterprises from the Czech Republic that were divided into three groups: 583 were in the group of enterprises creating value, 503 enterprises in bankruptcy or just before bankruptcy, and 829 other enterprises.

\begin{tabular}{|l|l|c|c|c|c|c|c|c|c|c|}
\hline \multicolumn{1}{|l|}{ Table 5: Results of IN99 } \\
\hline & $\mathbf{2 0 0 7}$ & $\mathbf{2 0 0 8}$ & $\mathbf{2 0 0 9}$ & $\mathbf{2 0 1 0}$ & $\mathbf{2 0 1 1}$ & $\mathbf{2 0 1 2}$ & $\mathbf{2 0 1 3}$ & $\mathbf{2 0 1 4}$ & $\mathbf{2 0 1 5}$ & $\mathbf{2 0 1 6}$ \\
\hline & 1.13 & 0.97 & 1.03 & 1.08 & 1.42 & 1.16 & 0.75 & 0.40 & 1.19 & 1.43 \\
\hline Rakhat & 0.66 & 0.96 & 0.68 & 0.73 & 0.65 & 0.62 & 0.62 & 0.68 & 0.79 & 0.89 \\
\hline Bayan Sulu & 1.04 & 0.78 & 1.12 & 0.10 & 0.75 & 0.79 & 1.27 & -1.68 & -12.66 & -3.45 \\
\hline Konfety K. & 0.62 & 0.58 & 0.70 & 0.71 & 0.81 & 0.77 & 0.80 & 0.70 & 0.75 & 0.73 \\
\hline Nestle & 1.20 & 0.53 & 1.54 & 0.87 & 0.34 & 0.34 & 0.13 & 0.43 & 0.08 & 0.20 \\
\hline Roshen & 1.63 & 1.48 & 1.89 & 1.32 & 1.14 & 0.83 & 0.58 & 0.70 & 0.77 & 0.97 \\
\hline KDV-Yashkino & 1.27 & 1.26 & 1.26 & 1.00 & 1.04 & 1.63 & 1.59 & 1.68 & 1.59 & 1.55 \\
\hline Konti & 1.26 \\
\hline
\end{tabular}

Source: Authors

IN99 focuses on the company through lenses of the owner. The greener the fields, the happier the owner. We can see that almost all companies had to experience very tough times in last decade. Besides already commented situation of KK, Rakhat shows relative ability to get out of surprising negative events as recession or depreciation faster than its competitors. Konti results are a surprise as in the environment of recession, frozen credit markets, depreciation of UAH and war in Ukraine remains in relatively much healthier conditions compared to the competition. In 2010 and 2011 the profit and stocks increased as well as bank credits. Total liabilities increased in 2010 by $64 \%$ from 2568139 to 4227610 UAH. Konti also did something the KK did not: converted all their debts in EUR and USD to UAH on September 9, 2009, so they evaded later depreciation of UAH that would hit them hard when the war with Russia-supported separatists started after the annexation of Crimea in 2014. Konti faced high Ukrainian interest rates between 2010 and 2011 (after the conversion of all debt to UAH the rates started to fall from around $26 \%$ to $17 \%$ ). (Audit reports for 2009 and 2011 from Konti reporting, 2017) In our opinion, the IN99 describes the conditions of analyzed companies in the given environment in a more vivid way than Altman's z-score, which also shows very useful and interesting results.

\section{IN01 Index}

The IN01 merges creditworthiness and bankruptcy models.

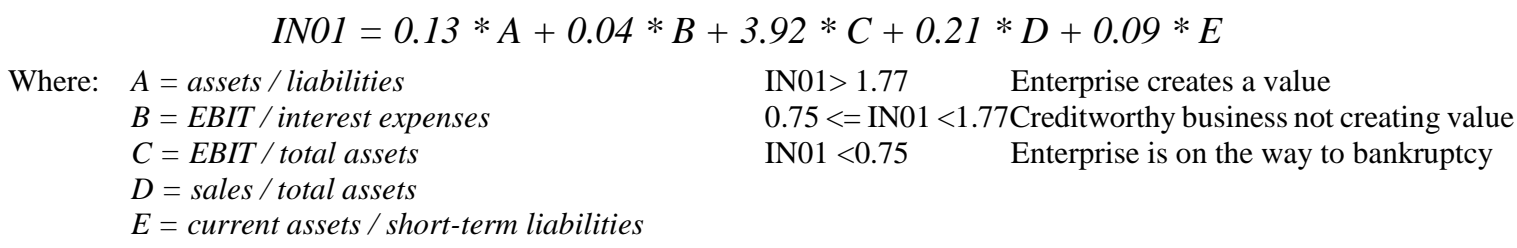

Together with IN05, the IN01 uses interest expenses which show especially in case of Konfety Karagandy serious problems with credit repayment. KK as mentioned went through a restructuring in 2014, in early summer of 2016 shut the production to buy new equipment. Date of production reopening is unknown. To be able to run analysis on KK, we had to limit the ceiling of the ratio EBIT / Interest expenses to 9 if the result was to be higher (in absolute value as well) to limit distortion of the z-score result. In fact (Neumaier \& Neumaierová, 2002) note that in similar cases (when the ratio would skyrocket up to infinity - including cases of zero interest expenses) the 9 is maximum value to be used. 
This ceiling we implemented affected results of IN01 and IN05 for Rakhat, KK, Nestle, Roshen, and KDV - Yaskino.

Table 6: Results of IN01

\begin{tabular}{|l|c|c|c|c|c|c|c|c|c|c|}
\hline & $\mathbf{2 0 0 7}$ & $\mathbf{2 0 0 8}$ & $\mathbf{2 0 0 9}$ & $\mathbf{2 0 1 0}$ & $\mathbf{2 0 1 1}$ & $\mathbf{2 0 1 2}$ & $\mathbf{2 0 1 3}$ & $\mathbf{2 0 1 4}$ & $\mathbf{2 0 1 5}$ & $\mathbf{2 0 1 6}$ \\
\hline Rakhat & 1.99 & 2.37 & 2.75 & 3.73 & 4.27 & 4.74 & 5.11 & 6.49 & 3.59 & 3.91 \\
\hline Bayan Sulu & 0.83 & 0.94 & 0.82 & 1.58 & 1.77 & 1.78 & 1.55 & 1.43 & 1.54 & 1.20 \\
\hline Konfety K. & 1.27 & 1.12 & 3.87 & 2.20 & 3.31 & 3.02 & 1.70 & -1.00 & -10.59 & -2.96 \\
\hline Nestle & 1.70 & 1.75 & 1.73 & 1.81 & 1.55 & 1.74 & 1.76 & 1.62 & 1.74 & 1.73 \\
\hline Roshen & 2.52 & 0.76 & 2.24 & 1.32 & 5.88 & 1.11 & 2.34 & 1.49 & 1.34 & 1.90 \\
\hline KDV-Yashkino & 2.11 & 2.21 & 2.68 & 2.26 & 1.93 & 1.25 & 1.09 & 0.92 & 0.87 & 1.22 \\
\hline Konti & 1.32 & 1.30 & 1.29 & 1.04 & 1.07 & 1.80 & 1.82 & 1.81 & 1.66 & 1.66 \\
\hline
\end{tabular}

Source: Authors

IN01 shows us a balanced view of the whole sector and points out just the financial distress of Konfety Karagandy.

\section{IN05 Index}

IN05 is the latest known index of Inka and Ivan Neumaier. This index is an update of the IN01 index of the Industrial Data Tests of 2004. The ratios are same with IN01. The index formula IN05 is:

$$
\text { IN05 }=0.13 * A+0.04 * B+3.97 * C+0.21 * D+0.09 * E
$$

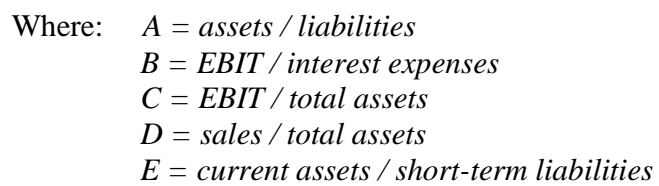

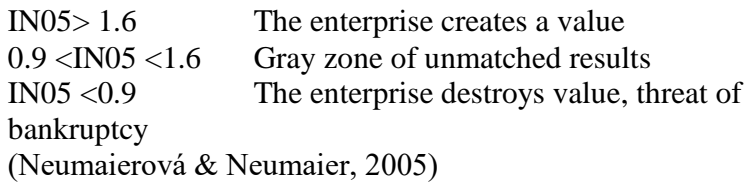

\begin{tabular}{|l|r|r|r|r|r|r|r|r|r|r|}
\hline Table 7: Results of IN05 \\
\hline & $\mathbf{2 0 0 7}$ & $\mathbf{2 0 0 8}$ & $\mathbf{2 0 0 9}$ & $\mathbf{2 0 1 0}$ & $\mathbf{2 0 1 1}$ & $\mathbf{2 0 1 2}$ & $\mathbf{2 0 1 3}$ & $\mathbf{2 0 1 4}$ & $\mathbf{2 0 1 5}$ & $\mathbf{2 0 1 6}$ \\
\hline Rakhat & 2.00 & 2.37 & 2.75 & 3.74 & 4.28 & 4.75 & 5.12 & 6.49 & 3.60 & 3.92 \\
\hline Bayan Sulu & 0.84 & 0.94 & 0.82 & 1.59 & 1.78 & 1.78 & 1.55 & 1.43 & 1.55 & 1.21 \\
\hline Konfety K. & 1.28 & 1.12 & 3.88 & 2.20 & 3.31 & 3.02 & 1.71 & -1.03 & -10.73 & -3.00 \\
\hline Nestle & 1.71 & 1.75 & 1.73 & 1.82 & 1.55 & 1.74 & 1.77 & 1.62 & 1.75 & 1.74 \\
\hline Roshen & 2.53 & 0.76 & 2.25 & 1.33 & 5.89 & 1.11 & 2.34 & 1.49 & 1.34 & 1.90 \\
\hline KDV-Yashkino & 2.12 & 2.23 & 2.69 & 2.27 & 1.93 & 1.25 & 1.09 & 0.93 & 0.87 & 1.23 \\
\hline Konti & 1.33 & 1.30 & 1.29 & 1.04 & 1.08 & 1.81 & 1.83 & 1.82 & 1.67 & 1.67 \\
\hline Source: Authors
\end{tabular}

IN05, on the other hand, shows more distressed periods of analyzed companies. KDV - Yaskino red field is caused by the significant increase in liabilities in 2014. Similarly, as KDV - Yaskino, Bayan Sulu, and Roshen red fields, just below the threshold, show period of depreciation and severe crisis in Ukraine (Roshen, compared with much more stable Konti). Bayan Sulu increased common capital in 2009 16-fold. Credits also increased significantly in 2009 while cash from operating activities was nearly non-existent.

\section{Creditworthiness index}

The creditworthiness index, also referred to as the creditworthiness indicator, is based on a multivariate discriminatory analysis based on a simplified method. It is mainly used in German-speaking countries. (Atlantis, 2017) The credit index (index) is calculated according to the formula:

$$
C I=1.5 * x 1+0.08 * x 2+10 * x 3+5 * x 4+0.3 * x 5+0.1 * x 6
$$

We used the following ratios:

$\mathrm{x} 1$ = cash flow / liabilities

$\mathrm{x} 2=$ total assets / liabilities

$\mathrm{x} 3=$ earnings before taxes / total assets

$\mathrm{x} 4=$ earnings before taxes / sales

$\mathrm{x} 5=$ stocks $/$ sales

$\mathrm{x} 6=$ sales $/$ total assets
Evaluation:

$-3<$ CI $<-2 \quad$ extremely bad

$-2<\mathrm{CI}<-1 \quad$ very bad

$-1<\mathrm{CI}<0$

$0<\mathrm{CI}<1$

$1<\mathrm{CI}<2$

$2<\mathrm{CI}<3$

$3<\mathrm{CI}$ bad

certain problems

good

very good

extremely good 


\begin{tabular}{|c|c|c|c|c|c|c|c|c|c|c|}
\hline & 2007 & 2008 & 2009 & 2010 & 2011 & 2012 & 2013 & 2014 & 2015 & 2016 \\
\hline Rakhat & 3.15 & 1.72 & 3.48 & 4.52 & 3.73 & 7.78 & 10.85 & 11.67 & 8.37 & 7.44 \\
\hline Bayan Sulu & 0.81 & 0.99 & 1.02 & 2.43 & 1.96 & 2.98 & 1.43 & 1.47 & 2.94 & 2.59 \\
\hline Konfety K. & 0.33 & 0.82 & 1.95 & -0.42 & 1.81 & 1.09 & 2.02 & -7.59 & -48.58 & -19.65 \\
\hline Nestle & 2.36 & 2.32 & 2.41 & 2.44 & 2.28 & 2.35 & 2.36 & 2.18 & 2.37 & 2.69 \\
\hline Roshen & 3.19 & 3.02 & 3.91 & 2.78 & 5.46 & 1.34 & 1.96 & 2.18 & 0.22 & 0.59 \\
\hline KDV-Yashkino & 3.17 & 3.44 & 4.11 & 2.61 & 2.37 & 0.99 & 0.64 & 1.06 & 0.55 & 0.93 \\
\hline Konti & 1.37 & 1.32 & 1.31 & 1.02 & 1.04 & 2.42 & 2.54 & 2.87 & 2.68 & 2.66 \\
\hline
\end{tabular}

Per model rules, we would normally use seven colors between dark green and dark red, but since KK showed statistics worse than -3 , which is outside statistics of the model, we marked the outside values with black color and white text. Otherwise, the model shows only Rakhat is truly creditworthy company while Konti, Nestle and recently also Bayan Sulu can also have relatively easy access to credit.

\section{Conclusion}

The IN models showed us certain "hand" intervention into the models is necessary because the market is very specific and offering one would say changing and significant permanent challenges. It is certainly not for beginners to operate in such a market. Another specific of the whole market is high interest rates causing fluctuating and hardly predictable interest expenses of all indebted companies. We see foreign exchange risk can cause even clinical death as in case of Konfety Karagandy. Depreciation linked to oil prices that plummeted during the Great Recession is a permanent threat because given current oil supply and demand trends it is unlikely the RUB and KZT currencies will strengthen in the near few years. Oil prices may even decrease a bit with next recession in the region, or with global problems that will sooner or later come, and companies will face distress conditions again. Such an environment cannot be called standard and regarding financial analysis methods and models certainly would appreciate similar approach as in the Czech Republic. In Prague, the Ministry of Industry and Trade through cooperation with the University of Economics in Prague operates a web portal where every company can enter their data and receive model results.

It is called Benchmarking Diagnostic System of INFA Financial Indicators. (MPO, 2007) This system serves businesses to verify their financial health and compare their results with the industry's best industry or industry-wide industries, identifying the company's major advantages and helping to reveal the biggest problems, being the very first step in their solution. It is the starting point for shaping and defining a business strategy. Our analysis showed that presented models could be effectively used for competitiveness analysis on the market with many challenges.

\section{References}

Agarwal, V., \& Taffler, R. J. (2007). Twenty-five years of the Taffler z-score model: Does it really have predictive ability? Accounting and Business Research(4), pp. 285-300. doi:http://dx.doi.org/10.1080/00014788.2007.9663313

Atlantis. (2017). Used bankruptcy and creditworthy models. Retrieved from http://www.finanalysis.cz/pouzite-bankrotnimodely.html

Bayan Sulu reporting. (2017). Bayan Sulu documents. Retrieved from http://www.kase.kz/ru/emitters/show/BSUL

BBC. (20. March 2014). Retrieved from http://www.bbc.com/russian/international/2014/03/140320_roschen_lipetsk_troubles

CHRIS-ICE. (2017). Historical Futures Prices: Cocoa Futures, Continuous Contract \#1. Non-adjusted price based on spotmonth continuous contract calculations. Raw data from ICE. Retrieved from Quandl.com: https://www.quandl.com/data/CHRIS/ICE_CC1-Cocoa-Futures-Continuous-Contract-1-CC1-Front-Month

CRF. (2017). Ratios and Formulas in Customer Financial Analysis. Retrieved from CRF online: https://www.crfonline.org/orc/cro/cro-16.html

Euromonitor. (2016). Confectionery in Kazakhstan. Executive Summary of Country report. Retrieved from http://www.euromonitor.com/confectionery-in-kazakhstan/report

Focus. (24. October 2010). Roshen postroit yeshche odnu konditerskuyu fabriku v Rossii [Roshen will build another confectionary factory in Russia]. Retrieved from https://focus.ua/money/145303/

Grünwald, R. H. (2007). Finanční analýza a plánování podniku [Financial analysis and business planning]. Praha: Ekopress. IMF. (2017). International Financial Statistics. Retrieved from International Monetary Fund: http://data.imf.org/regular.aspx?key=61545857

KDV - Yaskino reporting. (2017). KDV - Yaskino documents. Retrieved from http://www.list-org.com/company/9040 Kislingerová E. et al. (2010). Manažerské finance [Managerial Finance] (3 ed.). Praha: C.H. Beck. 
Kislingerová, E. H. (2008). Finanční analýza: krok za krokem [Financial analysis step by step]. Praha: C.H. Beck.

Konfety Karagandy reporting. (2017). Depository of financial reporting for Konfety Karagandy JSC at MoF of the RK. Retrieved from https://dfo.kz/ru/DfoObjects/objects/teaser-view/25976?ElDossierTabId=AuditReports

Konfety Karagandy. (2015). 2014 Audit report. Retrieved from https://dfo.kz/ru/DfoObjects/objects/teaserview/25976?ElDossierTabId=AuditReports

Konti Group. (2012, March 2). Retrieved from http://www.konti.com/upload/konti/content/26/Konti_october_2012_eng.pdf Konti reporting. (2017). Konti documents. http://www.list-org.com/company/5787.

MPO. (2007). Bechmarking diagnostic system of INFA Financial Indicators. Retrieved from Ministry of Industry and Trade: https://www.mpo.cz/cz/rozcestnik/analyticke-materialy-a-statistiky/benchmarkingovy-diagnosticky-system-financnichindikatoru-infa--30195/

NBK. (2017). USDKZT Daily Exchange Rate. Retrieved from National Bank of Kazakhstan: http://www.nationalbank.kz/?furl=cursFull\&switch=eng

Nestle reporting. (2017). Nestle documents. Retrieved from http://www.list-org.com/company/4366331

Neumaier, I., \& Neumaierová, I. (2002). Výkonnost a tržní hodnota firmy [Performance and market value of the company]. Praha: Grada Publishing.

Neumaierová, I., \& Neumaier, I. (2005). Index IN05. Sborník příspěvků z mezinárodní vědecké konference "Evropské finanční systémy" [Proceedings of the International Scientific Conference "European Financial Systems"] (pp. 143-148). Brno: Masaryk University.

NovoeTV. (2016, June 15). "Candies of Karaganda" suspend their production. Retrieved from http://novoetv.kz/2016/06/konfety-karagandy-priostanavlivayut-svoe-proizvodstvo/

Rakhat reporting. (2017). Rakhat documents. Retrieved from http://www.kase.kz/ru/emitters/show/RAHT

Rakhat. (2017). JSC Rakhat 2016 Annual Report. Retrieved from

http://www.kase.kz/files/emitters/RAHT/rahtp_2016_rus.pdf

Roshen reporting. (2017). Roshen documents. Retrieved from http://www.list-org.com/company/584976

Růčková, P. (2011). Finanční analýza: metody, ukazatele, využití v praxi [Financial analysis: methods, indicators, use in practice]. Praha: Grada Publishing.

Vochozka, M. (2011). Metody komplexního hodnocení podniku [Methods of comprehensive enterprise evaluation]. Praha: Grada Publishing.

World Bank. (2017). World Development Indicators. Retrieved from World Bank: https://data.worldbank.org/

Annex 1: Translation table (Russian - Czech - English)

\begin{tabular}{|l|l|l|}
\hline ПОКАЗАТЕЛЙ & UKAZATELE & INDICATORS \\
\hline $\begin{array}{l}\text { Долгосрочные финансовые } \\
\text { активы }\end{array}$ & Dlouhodobý finanční majetek & Long-term financial investments \\
\hline Оборотные активы & Oběžná aktiva & Current assets \\
\hline Дебиторская задолженность & Pohledávky & Account receivables \\
\hline $\begin{array}{l}\text { Долгосрочная дебиторская } \\
\text { задолженность }\end{array}$ & Dlouhodobé pohledávky & Long-term receivables \\
\hline $\begin{array}{l}\text { Краткосрочная дебиторская } \\
\text { задолженность }\end{array}$ & Krátkodobé pohledávky & Short-term receivables \\
\hline $\begin{array}{l}\text { Дебиторская задолженность } \\
\text { после срока оплаты }\end{array}$ & $\begin{array}{l}\text { Pohledávky po lhůtě } \\
\text { splatnosti }\end{array}$ & Past due receivables \\
\hline $\begin{array}{l}\text { Краткосрочные финансовые } \\
\text { активы }\end{array}$ & Krátkodobý finanční majetek & $\begin{array}{l}\text { Short-term financial investments (does not } \\
\text { include cash, only short term securities) }\end{array}$ \\
\hline Запасы & Zásoby & Inventories \\
\hline Итоги актива & Aktiva celkem & Total assets \\
\hline & & Vlastní kapitál \\
\hline Собственный капитал & Základní kapitál & $\begin{array}{l}\text { Owner's Equity (used in Altman as Market value } \\
\text { of Equity) }\end{array}$ \\
\hline Уставный капитал & Cizí kapitál & Common stock/Common capital/Share capital \\
\hline Заемный капитал & Nerozdělený zisk & Liabilities \\
\hline Нераспределенная прибыль & Retained earnings \\
\hline Долгосрочные обязательства & Dlouhodobé závazky & Long-term liabilities \\
\hline Краткосрочные обязательства & Krátkodobé závazky & Short-term liabilities \\
\hline $\begin{array}{l}\text { Краткосрочные и долгосрочные } \\
\text { обязательства }\end{array}$ & Celkové dluhy & Total liabilities \\
\hline $\begin{array}{l}\text { Обязательства после срока } \\
\text { оплаты }\end{array}$ & Závazky po lhůtě splatnosti & Past due liabilities \\
\hline Банковские кредиты и займы & Bankovní úvěry a výpomoci \\
\hline $\begin{array}{l}\text { Краткосрочные банковские } \\
\text { кредиты и займы }\end{array}$ & $\begin{array}{l}\text { Krátkodobé bankovní úvěry a } \\
\text { výpomoci }\end{array}$ & Short term bank and other borrowings \\
\hline
\end{tabular}


CBU INTERNATIONAL CONFERENCE ON INNOVATIONS IN SCIENCE AND EDUCATION

\begin{tabular}{|l|l|l|}
\hline Итоги пассива & Pasiva celkem & Total equity and liabilities \\
\hline Отчет о прибылях и убытках & Výkaz zisku a ztrát & Income statement \\
\hline Выручка & Tržby & Sales \\
\hline Себестоимость товаров и услуг & $\begin{array}{l}\text { Náklady na prodané výrobky } \\
\text { a služby }\end{array}$ & Cost of goods and services \\
\hline Валовый доход & $\begin{array}{l}\text { Hrubá marže z prodeje, resp. } \\
\text { Marže z prodeje }\end{array}$ & $\begin{array}{l}\text { Gross profit (=Gross margin), difference between } \\
\text { sales and cost of sales (cost of goods sold) }\end{array}$ \\
\hline Доходы & Výnosy & Income \\
\hline $\begin{array}{l}\text { Операционный результат } \\
\text { хозяйствования }\end{array}$ & $\begin{array}{l}\text { Provozní hospodářský } \\
\text { výsledek }\end{array}$ & Operating profit/loss \\
\hline $\begin{array}{l}\text { Результат хозяйствования за } \\
\text { отчетный период }\end{array}$ & $\begin{array}{l}\text { Hospodářský výsledek za } \\
\text { běžné období }\end{array}$ & Profit/loss for the (current) period \\
\hline Амортизация & Odpisy & Depreciation \\
\hline Процентные расходы & Nákladové úroky & Interest expenses \\
\hline Изменение статуса резерва & Změna stavu rezerv & Change in provisions \\
\hline $\begin{array}{l}\text { Прибыль до вычета процентов и } \\
\text { налогов }\end{array}$ & $\begin{array}{l}\text { Zisk před zdaněním a úroky }= \\
\text { EBIT }\end{array}$ & Earnings before interest and taxes \\
\hline Прибыль до налогообложения & Zisk před zdaněním = EBT & Earnings before taxes \\
\hline Прибыль после уплаты налогов & $\begin{array}{l}\text { Zisk po zdanění (čistý zisk) }= \\
\text { EAT }\end{array}$ & Earnings after taxes \\
\hline Добавленная стоимость & Přidaná hodnota & Value added \\
\hline Денежный поток & Peněžní toky (cash flow) & cash flows \\
\hline & $\begin{array}{l}\text { Pracovní kapitál = Oběžná } \\
\text { aktiva - Krátkodobé závazky }\end{array}$ & Working capital \\
\hline Рабочий капитал & \\
\hline
\end{tabular}

\section{Source: Authors}

